\title{
Epidemiology of Multidrug-resistant Organisms in Africa
} Afrika'daki Çok Ilaca Dirençli Organizmaların Epidemiyolojisi

\author{
(1) Bashar Haruna GULUMBE ${ }^{1}$, (1) Abdullahi Adamu FAGGO² \\ ${ }^{1}$ Federal University Birnin Kebbi Faculty of Science, Department of Microbiology, Kalgo, Nigeria \\ ${ }^{2}$ Bauchi State University Faculty of Science, Department of Microbiology, Bauchi, Nigeria
}

\section{Abstract}

Multidrug-resistant organisms/bacteria (MDROs) have significant health implications that either have not been addressed or received only limited attention, especially in resource-constrained settings such as Africa, where access to newer, often costly antibiotics is limited. Acquisition of MDROs has been linked with poorer clinical outcomes and prolonged hospitalization. The evolution and spread of MDROs is influenced by factors such as selective pressure exerted by indiscriminate use of antimicrobials in both agriculture and medicine, lack of prescribing skills and training, lack of access to rapid and reliable diagnostics, suboptimal surveillance, as well as poor implementation and adherence to prevention measures. Reports indicate increased occurrence of MDROs in Africa, including members of Enterobacteriaceae which are often implicated in bloodstream, urinary tract, abdomen, skin and soft tissue infections. However, serious data limitation and underreporting are major hurdles that continue to hinder our understanding of the impact of antimicrobial resistance. In this review, we sought to address this gap by providing up-to-date data on the epidemiology of MDROs across the continent, including data on their prevalence and current detection and prevention methods.

Keywords: ESKAPE, extremely drug-resistant, antibiotic resistance, bacteria, infection control

Öz

Çok ilaca dirençli organizmaların/bakterilerin (MDRO), genellikle yüksek fiyatlı olan yeni antibiyotiklere erişimin kısıtı olduğu, kaynak sıkıntısı yaşanan özellikle Afrika gibi bölgelerdeki sağlık üzerine olan önemli etkileri ele alınmamış veya sadece sınırlı ilgi görebilmiştir. Çok ilaca dirençli organizma enfeksiyonları, kötü klinik sonuçlar ve uzun hastanede kalma süresi ile ilişkilidir. MDRO'ların evrilmesi ve yayılması, antimikrobiyal ajanların hem tarımda hem de tıp alanında gelişigüzel kullanılmasıyla oluşan seçici baskı, reçete yazma becerisi ve eğitiminin eksikliği, hızlı ve güvenilir tanı araçlarına erişimin olmayışı, suboptimal sürveyans gibi faktörler kadar, önleyici yaklaşımların iyi uygulanmaması ve bu ilkelere bağlı kalınmamasından da etkilenir. Raporlar her ne kadar genellikle kan, idrar yolu, karın, deri ve yumuşak doku enfeksiyonlarına neden olan Enterobacteriaceae ailesi üyeleri de dahil olmak üzere MDRO'ların görülmesinde artış bildirmektedir. Buna karşı Afrika'da antimikrobiyal direncin etkisinin derecesinin kavranmasının önüne geçmeye devam eden esas faktörler ciddi veri eksikliği ve yetersiz bildirimdir. Bu derlemede, bu boşluğu, kıta genelinde MDRO'ların epidemiyolojisine dair, prevalansları hakkında veriler ve mevcut tanı ve önleme yöntemleri de dahil olmak üzere, güncel verilerle doldurmayı amaçladık.

Anahtar Kelimeler: ESKAPE, extremely drug-resistant, antibiyotik direnç, bakteri, enfeksiyon kontrolü

\section{Introduction}

In the 1970s, the emergence of antibiotics tremendously reduced both morbidity and mortality rates, leading to increased life expectancy, better quality of life, and increased wealth and productivity ${ }^{[1]}$. For the last 30 years, however, the evolution and spread of antimicrobial resistance (AMR) poses a significant threat to modern medical and surgical procedures globally, leading to higher rates of infection, treatment failure, and mortality ${ }^{[2,3]}$. Multidrug resistance/resistant (MDR) refers to the ability of bacteria to resist at least three classes of antibiotics (e.g., beta-lactamase inhibitor combination drugs, cephalosporins, and fluoroquinolones etc.), usually due to carriage of several resistance-associated genes ${ }^{[4]}$. Major multidrug-resistant organisms (MDROs) include methicillin/ oxacillin-resistant Staphylococcus aureus, vancomycin-

Cite this article as: Gulumbe BH, Faggo AA. Epidemiology of Multidrug-resistant Organisms in Africa. Mediterr J Infect Microb Antimicrob. $2019 ; 8: 25$. 
resistant enterococci, extended-spectrum beta-lactamase (ESBL) producers, penicillin-resistant Streptococcus pneumoniae, and MDR tuberculosis ${ }^{[4]}$. In the medical field, the terms extreme drug resistance/extensive drug resistance/extremely drug resistant/ extensively drug resistant (XDR) are widely used to describe bacteria that are not only resistant to multiple antimicrobial agents, but have the potential to resist all or nearly all approved antimicrobial agents ${ }^{[5]}$. Pan-drug-resistant organisms, on the other hand, are those resistant to nearly all commercially available antimicrobials or resistant to all antimicrobials routinely tested ${ }^{[5]}$.

The increasing incidence of MDROs in clinical and environmental specimens has been linked to many reasons. one of these is the extensive use of antimicrobials $s^{[4,6]}$. Extensive use of antimicrobials may increase selection pressure in a microbial population by allowing resistant microbes which could be $\mathrm{MDR}^{[1]}$ to survive and flourish in the ecological vacuum created by the death of susceptible bacteria ${ }^{[4]}$. Factors associated with predisposition to MDRO infection include colonization with MDR pathogens, high or cumulative antibiotic exposure, high severity of illness/care in an intensive care unit, prolonged acute-care hospitalization, recent antibiotic therapy (within three months), recent hospitalization (within three months), solid organ or bone marrow transplantation, and prolonged hospitalization ${ }^{[4]}$. In resource-constrained settings such as Africa, access to newer and often costly antibiotics such as plazomicin, colistin, and tigecycline (developed to treat MDR infections) is limited. Acquisition of MDROs has been linked to high morbidity and mortality rates, increased treatment costs, and prolonged hospitalization ${ }^{[7-9]}$. In both Africa and South-East Asia, for example, $45 \%$ of deaths have been attributed to MDR bacteria ${ }^{[0]}$. In Africa, the problem of MDROs is influenced by factors such as indiscriminate use of antimicrobials, poor prescribing skills and training, lack of access to rapid and reliable diagnostics, poor hand hygiene practices, lack of infection prevention data, and inadequate surveillance ${ }^{[7,10]}$.

Although reports indicate increased incidence of MDROs, including members of Enterobacteriaceae which are often implicated in bloodstream, urinary tract, abdominal, skin and soft tissue infections, limited data and underreporting of MDROs continue to be a problem in Africa ${ }^{[9,11,12]}$. Herein, we reviewed the published articles reporting the prevalence of MDROs, diagnostic tools used, and AMR prevention methods in the whole African region.

\section{Reasons for Evolution of Multidrug-resistant} Organisms

Antibiotic resistance predates the introduction of sulfanilamide and penicillin in the late 1930s and 1940s, respectively. Evolutionary pressure from clinical antibiotics has played a key role in the development and interspecies spread of MDR. The expansive use of antibiotics both in medicine and agriculture has been a significant driver of MDR bacteria ${ }^{[2,13,14]}$. Other factors linked to the evolution of MDR bacteria include inappropriate prescribing practices due to lack of diagnostic facilities and diagnostic uncertainty. In many resource-limited settings in Africa, physicians prescribe antibiotics without any laboratory diagnosis implicating a particular etiologic agent. In many cases, broad-spectrum antibiotics are administered to patients ${ }^{[4,15]}$. The practice of self-medication is another major driver of MDR. In many communities in Africa, easy access to antibiotics, including last-resort antibiotics, reduces hospital attendance because people can easily get antibiotics of choice with no prescription ${ }^{[16]}$. In these settings, drug retailers, some of whom have no form of medical training, diagnose and prescribe all sorts of antibiotics. Patients patronize them since they are cheaper, easy to access, and offer negotiable health services. In some communities, this type of facility is the only available healthcare ${ }^{[16]}$. The emergence of MDR has also been linked to incomplete, partial, or inappropriate antibiotic therapy and suboptimal antibiotic concentrations $s^{[4,17]}$. Lack of surveillance and poor national infection control practices such as absence of personal protective equipment, poor hygiene practice, and lack of adherence to standard general precautions in Africa are other major drivers of AMR across the continent. For example, only two countries (constituting 4.3\% of Africa) have national AMR plans in place and seven (14.9\%) have national infection prevention control policies. Furthermore, the World Health Organization (WHO) 2014 report identified Africa as a region without established AMR surveillance systems ${ }^{[18]}$. Several countries have implemented pilot surveillance projects. A national laboratory-based surveillance program for selected bacterial and fungal pathogens has been in place in South Africa. However, no African country has a national surveillance program that regularly generates representative, robust data on antimicrobial use and resistance ${ }^{[19]}$.

\section{Mechanisms of Multidrug-resistance}

MDROs employ different resistance mechanisms, including reduced outer membrane permeability, target site modification, efflux pump overexpression, expression of chromosomal AmpC beta-lactamases, and acquisition of beta-lactamases ${ }^{[2,21]}$.

\section{Prevalence of Multidrug-resistant Organisms}

Prevalence of MDROs vary by organism, region, country, hospital, or by unit within a facility worldwide. MDROs are so-named due to their ability to resist more than one antimicrobial agent in vitro ${ }^{[5]}$. Infections with MDROs may lead to inadequate or delayed antimicrobial therapy, and are usually associated with poorer patient outcomes ${ }^{[1-4]}$. 
In the past, infections due to MDROs mostly hospital-acquired, but in recent years more infections have been reported in communities ${ }^{[4]}$. In many parts of Africa, although there are serious problems with regards to monitoring AMR, sufficient published data suggests that MDROs are on the rise $\mathrm{e}^{[22,23]}$. The first WHO global surveillance report on antibiotic resistance published in 2014 cited the mortality rate due to MDR bacteria as $45 \%$ in both Africa and South-East Asia. The report further revealed that Klebsiella pneumoniae resistant to thirdgeneration cephalosporins was associated with up to $77 \%$ mortality in Africa ${ }^{[18]}$. Additionally, MDR amongst the major human infectious agents Enterococcus faecium, S. aureus, K. pneumoniae, Acinetobacter baumannii, Pseudomonas aeruginosa, and Enterobacter spp., collectively termed ESKAPE, is reported to be increasing in Africa ${ }^{[18]}$. ESKAPE pathogens have been increasingly recognized as threatening microorganisms largely due to their ability to 'escape' the effects of most antibiotics $^{[24]}$.

Recently, Founou et al. ${ }^{[25]}$ reported the overall carriage rates of ESBL-mediating MDR Gram-negative ESKAPE in a tertiary hospital in South Africa as 37.2\% (16/43), 42.3\% (11/26), and $57.1 \%(4 / 7)$ at admission, after $48 \mathrm{~h}$, and at discharge, respectively.

\section{Enterococcus faecium}

The emergence and spread of MDR among enterococci, even to newer drugs including last-resort antibiotics, continues to pose a significant concern globally ${ }^{[26]}$. Linezolid, daptomycin, quinupristin/dalfopristin, and tigecycline are typically drugs of choice frequently used in the treatment of serious infections and therapeutic complications secondary to MDR infections caused by Enterococcus spp. ${ }^{[26]}$.

Tfifha et al. ${ }^{[2]}$ at Sahloul Hospital, a university-affiliated hospital in Tunisia, evaluated different MDR bacteria including Enterococcus faecalis and E. faecium. All 320 (100\%) Enterococcus spp. isolates, including E. faecium (37.5\%), isolated from fecal samples from pig farms in Eastern Cape, South Africa were MDR (resistant to vancomycin, streptomycin, and cloxacillin), and to at least two different classes of antibiotics, with $300(93.8 \%)$ isolates being resistant to five or more antibiotics ${ }^{[28]}$.

\section{Multidrug-resistant $S$. aureus}

Studies have shown high prevalence of methicillin-resistant S. aureus (MRSA) in hospital settings in Cameroon (72\%), South Africa (52\%), Ethiopia (42.8\%), Nigeria (29.6\%), Kenya (27.7\%), Ivory Coast (16.8\%), and Morocco (14.4\%) ${ }^{[29]}$. MRSA is one of the most prevalent causes of healthcare-associated infections. A study conducted between 1994 and 1999 in
Kinshasa, Congo reported over 50\% MDR prevalence ${ }^{[30]}$. In a different study conducted in 2000-2006 in eastern Congo, 85-96\% resistance to ampicillin and chloramphenicol was reported ${ }^{[18]}$, whereas a more recent study in the same country demonstrated a low prevalence of organisms resistant to fluoroquinolones, azithromycin, and third-generation cephalosporin $^{[30]}$.

\section{Multidrug-resistant $K$. pneumoniae}

High prevalence of MDR K. pneumoniae has been blamed for high mortality rates in Africa in recent years ${ }^{[9]}$. In a study carried out in a tertiary hospital in Kenya, as high as $80 \%$ prevalence of MDR K. pneumoniae was recorded ${ }^{[31]}$. The isolates were highly resistant to ceftriaxone (87.2\%), gentamicin (82.8\%), and cefepime (85.4\%). A similar trend was reported in neighboring Tanzania. The authors attributed this trend of high antibiotic resistance to the common use of these antibiotics in the study area, suggesting the need for sensitization and antimicrobial stewardship programs $\mathrm{s}^{[31]}$. MDR K. pneumoniae isolates, which in 2017 were resistant to common antibiotics such as ampicillin, gentamicin, tetracycline, trimethoprim-sulfamethoxazole, and ceftriaxone, have been documented as prevalent in Kilifi, Kenya ${ }^{[32]}$. Similarly, in Nigeria, the prevalence of MDR K. pneumoniae was reported as $63.4 \% 0^{[33]}$. Moroh et al. ${ }^{[34]}$ reported on the diversity and antibiotic resistance of uropathogenic bacteria from Abidjan, Cote d'Ivoire and observed significant higher percentages of MDR and possible XDR bacteria strains from inpatients compared with outpatients. They further revealed that $K$. pneumoniae had $14.9 \%$ prevalence. Worryingly, this trend of high prevalence of MDR K. pneumoniae across Africa has created increasingly limited treatment options for the organism.

\section{Multidrug-resistant A. baumannit}

In a study conducted on a global scale in which 18,741 A. baumannii isolates were studied, up to $44 \%$ of the isolates were MDR. The study showed increased rates of MDR $A$. baumannii isolates from 23\% in 2004 to 63\% in 2014. In Africa, 249 of 407 isolates (61.2\%) were observed to be $\mathrm{MDR}^{[35]}$. In a 5-year retrospective study spanning 2011 to 2015 in South Africa, 6,351 (79.2\%) of 8,010 A. baumannii isolates were MDR, resistant to meropenem, imipenem, ciprofloxacin, piperacillintazobactam, and ceftazidime, although a decrease from $85 \%$ in 2012 to $70 \%$ in 2015 was observed ${ }^{[36]}$. Nwadike et al. ${ }^{[37]}$ observed a high rate of MDR (100\%) among Acinetobacter isolates and suggested the implementation of AMR stewardship programs in hospitals in southeastern Nigeria to prevent an explosion of MDR bacteria. 


\section{Multidrug-resistant $P$. aeruginosa}

MDR $P$. aeruginosa is emerging as a clinically significant pathogen not only in resource-limited settings, but also in developed countries ${ }^{[38]}$. In a study conducted with 558 P. aeruginosa isolates, 73 (13.1\%) were $\mathrm{MDR}^{[35]}$. In Enugu, southeastern Nigeria, Chika et al. ${ }^{[39]}$ used the modified doubledisk synergy and Hodge's test to identify carbapenemase and metallo- $\beta$-lactamases (MBL) producers and reported a MDR P. aeruginosa prevalence of $10 \%$.

\section{Multidrug-resistant Enterobacter spp.}

In 2017, low frequency of MDR was reported among Enterobacter spp. For example, 5 of 94 Enterobacter aerogenes isolates (5.3\%) and 47 of 494 Enterobacter cloacae isolates (7.5\%) were MDR ${ }^{[35]}$. However, the rates of MDR E. aerogenes increased from 3\% in 2004 to $9 \%$ in 2008 but then decreased to $1 \%$ in 2014 globally. In a separate study, the average resistance rate to carbapenems observed in Enterobacter spp. in Kwazulu-Natal, South Africa was $5 \%$, whereas resistance to ciprofloxacin was greater in $E$. cloacae $(16 \%)$ compared to E. aerogenes $(8 \%)^{[36]}$. In northern Nigeria, Yusuf et al. ${ }^{[33]}$ reported the highest prevalence (31.3\%) of MDR Enterobacter spp. in major hospitals in Kano.

Widespread MDR among members of the Enterobacteriaceae family has been reported in Africa. MDR Enterobacteriaceae, which are often associated with the production of ESBLs and carbapenem-resistant Enterobacteriaceae (CRE), were implicated in bloodstream, urinary tract, abdomen, skin and soft infections from both inpatients and outpatients at Aga Khan University Hospital in Nairobi, Kenya ${ }^{[40]}$. In South Africa, the prevalence of nosocomial MDR Enterobacteriaceae from blood cultures was around $15 \%$ in $2008^{[22]}$. In Ivory Coast, significantly high prevalence of MDR uropathogenic bacteria of genus Acinetobacter and Enterobacter were documented ${ }^{[41,42]}$.

\section{Multidrug-resistant Salmonella}

The evolution and spread of MDR Salmonella enterica serovar typhi (S. typhi) has had significant consequences for mortality rates from typhoid fever globally ${ }^{[29]}$. Although there are very few reports from Africa, available data indicate that MDR S. typhi has emerged, and effective treatment options are not accessible due to high cost. In developed countries, they are often associated with food-borne gastroenteritis. However, in parts of subSaharan Africa (SSA), non-typhoidal Salmonella (NTS) is a major cause of deadly bacteremia ${ }^{[41]}$. For instance, studies from Kenya have reported that community-acquired NTS is among the top three causes of death among children ${ }^{[43-45]}$. Non-typhoidal Salmonella resistance to fluoroquinolones was reported to be in the 3.8-6.1\% range in Congo ${ }^{[23,46,47]}$. Resistance patterns among
MDR NTS isolated in a study suggest that third-generation cephalosporins should be the drug of choice for treatment of infections caused by these organisms ${ }^{[30,48]}$. However, the use of these drugs should be avoided since they are associated with the emergence of ESBL-producing organisms.

There are many studies reporting the prevalence of ESBLproducing S. typhi in African countries ${ }^{[30]}$. Resistance to thirdgeneration cephalosporin in Togo, Ghana, Kenya, Malawi, and Mozambique was documented to be very low (with minimum inhibitory concentration higher than common for a susceptible population) and in some cases even totally absent ${ }^{[49,50]}$. On the contrary, higher levels of resistance in Salmonella enteritidis were observed from these countries ${ }^{[16,38]}$. The increasing prevalence of MDR among NTS has been linked to perceived competition for an ecological transmission niche between the two NTS serotypes ${ }^{[51]}$. Similarly, severity of illness and higher case-fatality rates in Salmonella infections have been attributed to the relatively high prevalence of MDR $S$. typhi, which are often concomitantly resistant to ampicillin, chloramphenicol, and trimetoprim/sulfamethoxazole. In Kenya, like in many African countries, sporadic outbreaks of MDR S. typhi have been reported ${ }^{[52]}$. Although fluoroquinolones, macrolides, and cephalosporins are the second-line choices for treatment of MDR S. typhi infections, these antibiotics are not readily available in most of rural SSA. Furthermore, available data indicate increasing resistance to these drugs ${ }^{[16]}$. For example, a survey conducted in the Democratic Republic of Congo between 2000 and 2010 consistently indicated high (above 30\%) prevalence of MDR S. typhi that were resistant to fluoroquinolones, with a marked upward trend in $2010^{[53,54]}$. Similarly, the prevalence of MDR S. typhi has been consistently increasing in Kenya since the first report of MDR S. typhi outbreaks in $1998^{[16]}$, when the prevalence of the MDR phenotype was 50-65\%, and recent reports indicate over 75\% prevalence of all S. typhi from the main referral hospital and private hospitals in Nairobi ${ }^{[55]}$. Similar trends of MDR S. typhi have been reported in South Africa and Egypt ${ }^{[16]}$. In SSA, molecular epidemiological studies have shown that MDR S. typhi outbreaks are dominated by haplotype 58 , a clade that is often associated with outbreaks in Southeast Asia $^{[49]}$.

\section{Multidrug-resistant Escherichia coli}

As in the case of other members of Enterobacteriaceae, alarming levels of resistance have been observed in E. coli. In a referral hospital in Uganda, from 314 enrolled patients with surgical site infections, 304 bacterial isolates were obtained, of which $72(23.7 \%)$ were MDR E. coli, most of which were being ESBL producers and resistant to all commonly available antibiotics ${ }^{[56]}$. In a survey carried out in Kenya, for example, a total of $912 \mathrm{E}$. coli clinical isolates were found to be resistant to 
ampicillin alone or a combination of ampicillin and other classes of beta-lactam antibiotics. A total of $247(27 \%)$ strains were ESBL producers and $142(16 \%)$ isolates exhibited resistance to combinations of aztreonam and multiple cephalosporins including ceftazidime ${ }^{[57-59]}$. MDR E. coli isolated from outpatient clinics in Kenya were highly resistant to ampicillin, trimethoprim/ sulfamethoxazole, streptomycin, and amoxicillin/clavulanic acid, which are commonly used in hospitals ${ }^{[60]}$. In Africa, $E$. coli has also been reported to be a major pathogen in surgical site infections. These have caused the problem of managing serious illness due to $E$. coli to become even worse. Data from several African countries, including Gabon, Nigeria, and Tanzania report that resistance among causative organisms of diarrheal infections, such as enterotoxigenic, enteropathogenic, and enteroaggregative E. coli, is high $(38-60 \%)^{[61]}$. Typically, enteroaggregative $E$. coli are MDR and are one of the most common causes of diarrhea in children ${ }^{[22]}$. Studies among healthy populations have indicated that normal flora constitute a significant reservoir of genetic material from which pathogens can readily acquire resistance on mobile elements ${ }^{[22]}$. In addition, studies in Nigeria, Ghana, and Zimbabwe have shown that urban dwellers were more likely to carry MDR $E$. coli than rural or provincial residents ${ }^{[62]}$. These findings are concerning due to the rapid rate of urbanization and rural-urban migration in these countries and other parts of the continent ${ }^{[63]}$. The problem of diarrheal disease is aggravated by issues such as malnutrition, failure to control the spread of diarrheal pathogens due to poor sanitation and hygiene practices, and failure to contain resistant organisms and resistance genes due to poor surveillance and suboptimal health systems ${ }^{[63,64]}$.

\section{Acquisition of Multidrug-resistant Organisms}

MDROs may be acquired in both clinical and community settings and are usually difficult to treat ${ }^{[63]}$. In the hospital setting, transmission and persistence of MDROs is influenced by factors such as the number and the type of organism, the presence of susceptible individuals, selective pressure exerted by antimicrobial use, increased potential for transmission from larger numbers of colonized or infected patients, as well as the impact of implementation and adherence to infection control measures ${ }^{[63]}$. Patients with severe disease, particularly those with impaired immunity due to underlying medical conditions; recent surgery; or indwelling medical devices such as urinary catheters or endotracheal tubes are all vulnerable to MDRO colonization ${ }^{[6]}$. Long-term healthcare facilities have been linked to the dissemination of MDROs. Patients, especially those in the ICU, tend to have more risk factors than non-hospitalized patients ${ }^{\left[{ }^{[3]}\right]}$. Additional factors that can facilitate transmission of MDROs in hospital include chronic sinusitis, upper respiratory infection, and dermatitis ${ }^{[62]}$. Epidemiological evidence suggests that MDROs can be transmitted from patient to clinician or environmental surfaces and vice versa. This may be especially true in resource-constrained settings with limited adherence to hygiene guidelines.

The link between community and healthcare acquisition of CRE has been previously described ${ }^{[62]}$. Individuals with a history of frequent exposure to MDROs in a healthcare facility may easily bring about community acquisition of MDROs, especially in settings with limited surveillance ${ }^{[65]}$. CRE infections can be acquired in both clinical and community settings and are extremely difficult to treat. CRE, particularly E. coli and $K$. pneumoniae, were relatively uncommon causes of hospitalacquired infections until about two decades ago, and have since doubled in prevalence in recent years ${ }^{[6]}$. Isolation of patients helps reduce patient-to-patient transmission of CRE, and has led to a significant reduction of CRE infections in patients with confirmed CRE colonization at the time of admission, whether symptomatic or not ${ }^{[67]}$. The number of individuals that develop infection after colonization remains unclear ${ }^{[68]}$. In a systematic review evaluating 1,806 hospitalized patients identified as colonized with CRE at the time of admission, only 299 (16.5\%) were found to develop infection ${ }^{[65]}$. Evidence suggests that longterm hospitalization plays a critical role in the dissemination of CRE. Therefore, early detection of CRE in patients admitted to healthcare facilities may help mitigate institutional outbreaks and halt regional spread of CRE ${ }^{[67]}$.

The dissemination of CRE in the community is largely via carriage in commensal microflora, which might go undetected unless disease symptoms manifest ${ }^{[69]}$. In poor African communities with limited healthcare facilities, even when symptoms develop, limited diagnostic and treatment options continue to promote dissemination of CRE among the population in affected communities.

The link between community and healthcare acquisition of CRE has been previously described by Sekyere et al. ${ }^{[70]}$, who reported that New Delhi metallobeta-lactamase (NDM)-producing microorganisms isolated with high frequency in healthcare facilities and environmental niches disseminated into the community through patient transfer. Individuals who have a history of frequent exposure to CRE in a healthcare facility may easily spread CRE within the communities in Africa. Reports reveal that bacteria carrying the NDM enzyme may find its way outside the boundaries of hospital settings into community water and sewage environments ${ }^{[71]}$.

Although the exact molecular epidemiology of carbapenemases and their genetic environment have not been well studied in Africa, the bla0XA-48, blalMP, blaVIM, and blaNDM in A. baumannii, K. pneumoniae, E. cloacae, Citrobacter spp. and E. coli, are the dominant carbapenemase genes characterized to date ${ }^{[69]}$. 
In North Africa, carbapenem hydrolyzing enzymes have been documented in countries such as Algeria, Tunisia, Morocco, Libya, and Egypt among Enterobacteriaceae species. In Algeria, the first documented carbapenemase among Enterobacteriaceae was the VIM-19 enzyme in $E$. coli and $K$. pneumoniae ${ }^{[72]}$. In Tunisia ${ }^{[73]}$, Bathoorn et al detected $K$. pneumoniae harboring blaVIM-4 for the first time, which was co-expressed with blaCTX-M-15 and blaCMY-4. Similarly, samples collected from patients of armed conflict from Libya and tested in Europe were positive for bla0XA-48 and bla0XA-23 in K. pneumoniae (ST101, ST147, ST383, and ECI). OXA-48 and NDM-1-producing Enterobacteriaceae in environmental, clinical, and community settings have been reported to be prevalent in Morocco ${ }^{[74]}$. Most class D carbapenemases (OXA-48 and bla0XA-48) were detected in Egypt from K. pneumoniae and E. coli in clinical specimens ${ }^{[75]}$.

South Africa has published more articles on CRE than any other African country. Since 2012, the South African National Antimicrobial Resistance Reference Laboratory has reported a total of 1,618 carbapenem nonsusceptible isolates from all specimen types. Of the 1,258 Enterobacteriaceae isolates identified, 1,043 (83\%) were confirmed to have carbapenem resistance genes ${ }^{[74]}$. K. pneumoniae carbapenemase-2 (KPC) was first detected in South Africa in 2012 ${ }^{[69]}$ and is the most frequently reported carbapenemase in South Africa. Others such as bla0XA-48-like genes, have been found in K. pneumoniae, and in rare cases, E. coli and E. cloacae, where they mediate MDR. The first documented case of a blaNDM-1 in South Africa was in 2011 from a 63-year-old patient ${ }^{[76]}$. In the same year, the first blaKPC case (blaKPC-2) in South Africa was identified from E. cloacae and K. pneumoniae ${ }^{[39]}$.
In West Africa, Nigeria and Ghana are the leading countries in the region that have documented data regarding $\mathrm{CRE}^{[77]}$. In Nigeria, a study reported carbapenemase prevalence of 33.5\% in a hospital setting ${ }^{[6]}$, and Codjoe ${ }^{[78]}$ reported $12.5 \%$ and $15.4 \%$ carbapenemase production in E. coli and K. pneumoniqe isolates. Ogbolu and Webber ${ }^{[79]}$ identified blaNDM, blaVIM, and blaGES among $P$. aeruginosa, Proteus spp., K. pneumoniae and E. coli, respectively as the genes responsible for resistance in $\beta$-lactam antibiotics in Nigeria. Oladipo et al. ${ }^{[6]}$ reported a high rate of resistance to ertapenem (30\%), levofloxacin (20\%), and colistin sulfate $(4 \%)$ in $E$. coli isolated from clinical specimens, which they suggested could be as a result of plasmid transfer of AMR genes.

In Ghana, a recent study involving 111 carbapenem-resistant Gram-negative bacteria showed that none of the isolates harbored KPC genes. However, the carbapenemase genes identified were blaNDM-1, b/aVIM-1 and blaOXA-48 in $A$. baumannii, Pseudomonas species, and K. pneumoniae, respectively ${ }^{[78]}$. In Uganda, a study by Okoche et al. ${ }^{[80]}$ found carbapenemase prevalence of $22.4 \%$ and $28.6 \%$ using phenotypic and genotypic tests. In a recent study from the same country, among 56 isolates positive for carbapenemase-encoding genes, K. pneumoniae was the species with the highest number (52.2\%) and most prevalent genes were b/aVIM $(21,10.7 \%)$, blaOXA-48 $(19,9.7 \%)$, blalMP $(12,6.1 \%)$, blaKPC $(10,5.1 \%)$ and blaNDM-1 $(5,2.6 \%)^{[79]}$. In Kenya, carbapenemase gene was first reported in 2011 in a K. pneumoniae isolate (ST14) harboring an blaNDM-1 on a $120 \mathrm{kblncA} / \mathrm{C}$ plasmid ${ }^{[0,81]}$. In a 5 -year prospective study conducted between 2007 and 2012 in Tanzania, Mushi et al. ${ }^{[82]}$ documented blaIMP, blaVIM, bla0XA-48, and blaKPC in E. coli,

Table 1. Carbapenem-resistant Enterobacteriaceae genes in circulation in African countries

\begin{tabular}{|c|c|c|}
\hline Country & Carbapenem resistance genes & References \\
\hline Algeria & OXA, NDM, KPC and VIM & Robin et al. ${ }^{[83]}$ \\
\hline Angola & NDM and OXA & Kieffer et al. ${ }^{[84]}$ \\
\hline Egypt & OXA & Bathoorn et al. ${ }^{[73]}$ \\
\hline Gabon & NDM & Moussounda et al. ${ }^{[85]}$ \\
\hline Ghana & KPC, NDM, VIM and OXA & Codjoe $^{[78]}$ \\
\hline Kenya & NDM & Poirel et al. ${ }^{[81]}$, Mitgang et al. ${ }^{[86]}$ \\
\hline Madagascar & NDM and OXA & Mitgang et al. ${ }^{[86]}$ \\
\hline Mali & OXA & Sangare et al. ${ }^{[87]}$ \\
\hline Nigeria & OXA, NDM, GES and VIM & Chika et al. ${ }^{[39]}$, Yusuf et al ${ }^{[77]}$, Ogbolu and Webber ${ }^{[79]}$ \\
\hline Senegal & OXA & Mitgang et al. ${ }^{[86]}$ \\
\hline Serra Leone & OXA, VIM and DIM & Mitgang et al. ${ }^{[86]}$ \\
\hline South Africa & OXA, NDM, KPC, GES and porin & Perovic et al. ${ }^{[74]}$, Lowman et al. ${ }^{[76]}$ \\
\hline Tanzania & OXA, NDM, KPC, VIM and IMP & Mushi et al. ${ }^{[82]}$ \\
\hline Uganda & OXA, KPC, VIM and IMP & Okoche et al. ${ }^{[80]}$ \\
\hline
\end{tabular}

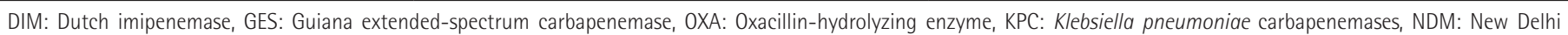
metallobeta-lactamase, VIM: Verona integron-encoded metallo- $\beta$-lactamases, IMP: Imipenem-resistant Pseudomonas 
K. pneumoniae, P. aeruginosa, and Salmonella in 80 out of 227 isolates and found that $21.6 \%$ of the 227 isolates harbored IMP genes (Table 1).

\section{Current Detection Tools}

Laboratory capacity to detect MDR in Africa is seriously limited ${ }^{[88]}$. Methods currently employed in the detection of MDR generally include phenotypic and molecular techniques. In routine laboratory practice, phenotypic methods may be used to identify the presence of acquired resistance mechanisms among frequently isolated nosocomial pathogens ${ }^{[89]}$. They are widely used for beta-lactamases that especially hydrolyzes carbapenems together with other beta-lactams (carbapenemases) ${ }^{[00,91]}$. Phenotypic methods of AMR detection include the doubledisk synergy test, which is used for the detection of betalactamases that are inhibited by beta-lactamase inhibitors such as clavulanic acid ${ }^{[21]}$, imipenem-EDTA synergy test, used for the phenotypic detection of MBL production in clinical isolates ${ }^{[92]}$, and the boronic acid test, which was proposed for the phenotypic detection of KPC producers, is easier to perform than the double-disk synergy test, and is more sensitive (with reported sensitivity of 100\%) $)^{[21]}$. A test that combines EDTA and the boronic acid test in a single plate with the ability to discriminates between carbapenem-susceptible, KPC-producing, MBL-producing, and double carbapenemase-producing bacteria has been introduced ${ }^{[93]}$. Other phenotypic tests include the Hodge test, used to detect carbapenemase production ${ }^{[94]}$, but has the disadvantage of inability to discriminate between different carbapenemase types ${ }^{[20]}$; the D-test, used for the detection of inducible AmpC beta-lactamases ${ }^{[95]}$, and carbonyl cyanide $\mathrm{m}$-chlorophenyl hydrazine, used to detect efflux pump overexpression that contributes to or determines carbapenem resistance ${ }^{[96]}$.

Classical in vitro phenotypic methods are widely adopted in African settings because they require little technical skill and are relatively cheap ${ }^{[95]}$. However, the limitations of these methods include lack of specificity, sensitivity, and importantly, most will not detect genetic resistance mechanisms in microorganisms ${ }^{[96]}$. In addition, most phenotypic techniques are time consuming, yielding results in typically around $17 \mathrm{~h}^{[96]}$. Hence, this causes a need to employ molecular methods like polymerase chain reaction $(P C R)^{[21]}$. These limitations highlight the need for detection tools that are not only sensitive, specific, and affordable but also rapid. Rapid detection of MDROs is desirable since it helps physicians make timely treatment decisions and help public health stakeholders take action to prevent and control the infections ${ }^{[97]}$.

Many instrumental techniques such as molecular techniques, microarrays, commercial methods used in routine work, immunochromatographic techniques, colorimetric methods, imaging methods, nephelometry, matrix-assisted laser desorption ionization-time of flight (MALDI-TOF) mass spectrometry, flow cytometry, chemiluminescence and bioluminescence, microfluids, and bacterial lysis methods that allow rapid antibiotic susceptibility results are available in developed nations but not in many African countries ${ }^{[95]}$. Molecular techniques are important detection tools which have played a significant role in understanding the epidemiology of MDR organisms. They detect resistance genes based on nucleic acid hybridization and amplification ${ }^{[98]}$. The techniques have been employed widely in both research and diagnostic laboratories ${ }^{[96]}$. Some of the methods used, such as PCR and hybridization techniques, have been used for decades, whereas methods such as whole-genome sequencing and MALDI-TOF mass spectrometry are just evolving ${ }^{[4]}$. PCR techniques, including commercial and automated, and PCR kits have been used to accurately detect a large number of genes that confer antibiotic resistance with a sensitivity and a specificity of nearly $100 \% 0^{[4]}$. The limitation of these methodologies is that they do not provide microbial identification and are generally applied to colonies grown on isolation plates ${ }^{[96]}$. Similarly, molecular techniques are not only laborious and time-consuming to perform, but also expensive ${ }^{[4]}$. These have hampered their deployment in resourcelimited settings. Moreover, many laboratories in Africa may be unable or unwilling to adopt these techniques under budgetary constraints ${ }^{[1,63]}$. Therefore, these laboratories, especially at the primary healthcare level, are unable to incorporate antibiotic susceptibility testing as an important part of routine laboratory practice.

Some of the preeminent kits available to detect antibiotic resistance genes included Light Mix (Roche Diagnostics) and Check-Direct CPE (Check-Points Health B.V.). The advantage of using kits is that they are rapid and less laborious. The Light Mix kit, using the LightCycler 480 Instrument II platform (Roche Diagnostics), for example, can detect KPC, NDM, VIM, IMP, and OXA-48 carbapenemases in less than two hours ${ }^{[99]}$.

\section{Conclusion}

Overall, significant prevalence rates of MDROs as well as high levels of drug resistance to commonly prescribed antibiotics such as ampicillin, gentamicin, and ceftriaxone have been reported across Africa. Therefore, treatment of bacterial infections must be well guided by local assessment of AMR. Lack of surveillance and significant data limitation from most of the countries on the continent regarding the prevalence of MDR are of great concern ${ }^{[99]}$. Unfortunately, in reality, most African countries have not fully recognized how significant a threat MDROs pose to public health.

Tackling the menace of MDR requires a strong global political will and sustained efforts, understanding of the nature 
and extent of MDROs, well-coordinated AMR regional and national action plans, and a sustained multi-stakeholder and multidisciplinary evidence-based approach ${ }^{[19,63]}$. In addition, existing antimicrobial stewardship programs should be sustained and strengthened to cover where such programs are not in place. Healthcare facilities should be enhanced to improve their capacity to diagnose and prevent disease before they escalate and appropriate treatment should be prescribed. This may be achieved through training and retraining of both laboratory and pharmacy staff in antibiotic stewardship at healthcare facilities where laboratory investigations are available ${ }^{[99]}$. Procedures for ongoing assessment of the quality of test reagents and test performance by clinical laboratory technicians should be available at healthcare facilities. Laboratories should also participate in national and/or external quality assurance programs in addition to the regular internal quality control practices. Building laboratory capacity will enable the generation of adequate and reliable AMR data that can guide policy actions to combat $\mathrm{AMR}^{[87]}$. In resource limited countries, insufficient human and financial resources and microbiology expertise continue to hinder the implementation of AMR programs. Therefore, new approaches to antimicrobial surveillance are needed ${ }^{[99]}$. In primary healthcare facilities with limited diagnostic capacity, rapid diagnostic kits that are specific and sensitive should be readily available and affordable. The development of new point-ofcare diagnostic tools that are able to detect AMR in a costeffective way will improve patient management and limit the emergence of drug resistance ${ }^{[99]}$. In each country, routine AMR surveys should be established to provide evidence-based and locally relevant antibiotic resistance data that would be helpful in creating guidelines to improve clinical practice ${ }^{[9]}$. Proper infection-control practice is central to decreasing the risk of emergence of MDR organisms. Therefore, improved sanitation and hygiene, which are still lacking in many parts of Africa, should be prioritized.

\section{Ethics}

Peer-review: Externally and internally peer-reviewed.

\section{Authorship Contributions}

Concept: B.H.G., A.A.F., Design: B.H.G., A.A.F., Data Collection or Processing: B.H.G., A.A.F., Analysis or Interpretation: B.H.G., A.A.F., Literature Search: B.H.G., A.A.F., Writing: B.H.G., A.A.F.

Conflict of Interest: No conflict of interest was declared by the authors.

Financial Disclosure: The authors declared that this study received no financial support.

\section{References}

1. Osei Sekyere J. Current State of Resistance to Antibiotics of Last-Resort in South Africa: A Review from a Public Health Perspective. Front Public Health. 2016;4.209.

2. Kouegnigan Rerambiah L, Ndong JC, Mbakob Mengue Massoua P, Medzegue S, Elisee-Ndam M, Mintsa-Ndong A, Djoba Siawaya JF. Antimicrobial profiles of bacterial clinical isolates from the Gabonese National Laboratory of Public Health: data from routine activity. Int J Infect Dis. 2014;29:48-53.

3. Okoh Al, Igbinosa EO. Antibiotic susceptibility profiles of some Vibrio strains isolated from wastewater final effluents in a rural community of the Eastern Cape Province of South Africa. BMC Microbiol. 2010;10:143.

4. Barie PS. Multidrug-resistant organisms and antibiotic management. Surg Clin AM. 2012;92:345-91.

5. Magiorakos AP, Srinivasan A, Carey RB, Carmeli Y, Falagas ME, Giske CG, Harbarth S, Hindler JF, Kahlmeter G, Olsson-Liljequist B, Paterson DL, Rice LB, Stelling J, Struelens MJ, Vatopoulos A, Weber JT, Monnet DL. Multidrugresistant, extensively drug-resistant and pandrug-resistant bacteria: an international expert proposal for interim standard definitions for acquired resistance. Clin Microbiol Infect. 2011;18:268-81.

6. Oladipo EK, Ajibade OA, Akinade SB, Alabi OA, State 0, State 0. Antimicrobial Resistance Pattern of Clinical Isolates of Pseudomonas aeruginosa and Escherichia coli on Carbapenems. Afr J Clin Exp Microbiol. 2018;19:159-64.

7. Maina D, Revathi G, Whitelaw AC. Molecular characterization of multidrugresistant Klebsiella pneumoniae and Escherichia coli harbouring extended spectrum beta-lactamases and carbapenemases genes at a tertiary hospital, Kenya. Microbiol Medica. 2017;32.

8. Revathi G, Siu LK, Lu PL, Huang LY. First report of NDM-1-producing Acinetobacter baumannii in East Africa. Int J Infect Dis. 2013;17:1255-8.

9. Founou RC, Founou LL, Essack SY. Clinical and economic impact of antibiotic resistance in developing countries: A systematic review and meta-analysis. PLoS ONE. 2017;12:e0189621.

10. Okeke I, Lamikanra A, Edelman R. Socioeconomic and behavioral factors leading to acquired bacterial resistance to antibiotics in developing countries. Emerg Infect Dis. 1999;5:18-27.

11. Manenzhe RI, Zar HJ, Nicol MP, Kaba M. The spread of carbapenemaseproducing bacteria in Africa: a systematic review. J Antimicrob Chemother. 2014;70:23-40.

12. Tadesse BT, Ashley EA, Ongarello $S$, Havumaki J, Wijegoonewardena $M$ González IJ, Dittrich S. Antimicrobial resistance in Africa: a systematic review. BMC Infect Dis. 2017;17:616.

13. Llor C, Cots JM. The sale of antibiotics without prescription in pharmacies in Catalonia, Spain. Clin Infect Dis. 2009;48:1345-9.

14. Kimang AN. A Situational Analysis of Antimicrobial Drug Resitance in Africa: Are We Losing The Battle? Ethiop J Health Sci. 2012;22:135-43.

15. Moghnieh R, Estaitieh N, Mugharbil A, Jisr T, Abdallah DI, Ziade F, Sinno L, Ibrahim A. Third generation cephalosporin resistant Enterobacteriaceae and multidrug resistant gram-negative bacteria causing bacteremia in febrile neutropenia adult cancer patients in lebanon, broad spectrum antibiotics use as a major risk factor, and correlation w. Front Cell Infect Microbiol. 2015;5:11.

16. Kariuki $S$, Dougan G. Antibacterial resistance in sub-Saharan Africa: an underestimated emergency. Ann N Y Acad Sci. 2015;1323:43-55.

17. Garnacho-Montero J, Garcia-Garmendia JL, Barrero-Almodovar A, JimenezJimenez FJ, Perez-Paredes C, Ortiz-Leyba C. Impact of adequate empirical antibiotic therapy on the outcome of patients admitted to the intensive care unit with sepsis. Crit Care Med. 2003;31:2742-51.

18. WHO. Antimicrobial Resistance. In: Global Report on surveillance. Edited by WHO. Geneva, Switzerland, 2014. Last accessed date: 18.10.2018. 
Available from: https://www.who.int/antimicrobial-resistance/publications/ surveillancereport/en/.

19. Essack SY, Desta AT, Abotsi RE, Agoba EE. Antimicrobial resistance in the WHO African region: current status and roadmap for action. J Public Health (Oxf). 2016;39:8-13.

20. Zubair KO, Iregbu KC. Resistance Pattern and Detection of Metallobeta-lactamase Genes in Clinical Isolates of Pseudomonas aeruginosa in a Central Nigeria Tertiary Hospital. Niger J Clin Pract. 2018;21:17682.

21. Georgios M, Egki T, Effrosyni S. Phenotypic and Molecular Methods for the Detection of Antibiotic Resistance Mechanisms in Gram Negative Nosocomial Pathogens. In: Trends in Infectious Deseases, 2014. Last accessed date: 18.10.2018. Available from: https://www.intechopen. com/books/trends-in-infectious-diseases/phenotypic-and-molecularmethods-for-the-detection-of-antibiotic-resistance-mechanisms-ingram-negat].

22. Okeke IN, Aboderin OA, Byarugaba DK, Ojo KK, Opintan JA. Growing problem of multidrug-resistant enteric pathogens in Africa. Emerg Infect Dis. 2007;3:1640-6.

23. Ampaire L, Muhindo A, Orikiriza P, Mwanga-Amumpaire J, Bebell L, Boum Y. A review of antimicrobial resistance in East Africa. Afr J Lab Med. 2016;5:432.

24. Kejela $T$, Bacha K. Prevalence and antibiotic susceptibility pattern of methicillin-resistant Staphylococcus aureus (MRSA) among primary school children and prisoners in Jimma Town, Southwest Ethiopia. Ann Clin Microbiol Antimicrob. 2013;12:11.

25. Founou RC, Founou LL, Essack SY. Extended spectrum beta-lactamase mediated resistance in carriage and clinical gram-negative ESKAPE bacteria: a comparative study between a district and tertiary hospital in South Africa. Antimicrob Resist Infect Control. 2018;7:1-11.

26. Ahmed MO, Baptiste KE. Vancomycin-Resistant Enterococci: A Review of Antimicrobial Resistance Mechanisms and Perspectives of Human and Animal Health. Microb Drug Resist. 2018;24:590-607.

27. Tfifha M, Ferjani A, Mallouli M, Mlika N, Abroug S, Boukadida J. Carriage of multidrug-resistant bacteria among pediatric patients before and during their hospitalization in a tertiary pediatric unit in Tunisia. Libyan J Med. 2017;13:1419047.

28. Iweriebor BC, Obi LC, Okoh Al. Virulence and antimicrobial resistance factors of Enterococcus spp. isolated from fecal samples from piggery farms in Eastern Cape, South Africa. BMC Microbiol. 2015;15:136.

29. Vandenberg O, Nyarukweba DZ, Ndeba PM, Hendriksen RS, Barzilay EJ, Schirvel C, Bisimwa BB, Collard JM, Aidara Kane A, Aarestrup FM. Microbiologic and clinical features of Salmonella species isolated from bacteremic children in eastern Democratic Republic of Congo. Pediatr Infect J. 2010;29:504-10.

30. Lunguya O, Lejon V, Phoba MF, Bertrand S, Vanhoof R, Glupczynski Y, Verhaegen J, Muyembe-Tamfum JJ, Jacobs J. Antimicrobial Resistance in Invasive Non-typhoid Salmonella from the Democratic Republic of the Congo: Emergence of Decreased Fluoroquinolone Susceptibility and Extended-spectrum Beta Lactamases. PLoS Negl Trop Dis. 2013;7:2013.

31. Apondi OE, Oduor OC, Gye BK, Kipkoech MK. High Prevalence of Multidrug Resistant Klebsiella in a Tertiary Teaching Hspital in Western Kenya. Afr J Infect Dis. 2016;10:89-95.

32. Henson SP, Boinett CJ, Ellington MJ, Kagia N, Mwarumba S, Nyongesa S, Mturi N, Kariuki S, Scott JAG, Thomson NR, Morpeth SC. Molecular epidemiology of Klebsiella pneumoniae invasive infections over a decade at Kilifi County Hospital in Kenya. Int J Med Microbiol. 2017;307:422-9.

33. Yusuf I, Arzai $A$, Haruna M, Sharif AA, Getso MI. Detection of multi drug resistant bacteria in major hospitals in Kano, North-West, Nigeria. Braz J Microbiol. 2014;45:791-8.
34. Moroh JLA, Fleury Y, Tia H, Bahi C, Lietard C, Coroller L, Edoh V, Coulibaly A, Labia $R$, Leguerinel I. Diversity and antibiotic resistance of uropathogenic bacteria from Abidjan. Afr J Urol. 2014;20:18-24.

35. Giammanco A, Calà C, Fasciana T, Michael JD. Global Assessment of the Activity of Tigecycline against Multidrug-Resistant Gram-Negative Pathogens between 2004 and 2014 as Part of the Tigecycline Evaluation and Surveillance Trial. mSphere. 2017;2:e00310-16.

36. Ramsamy Y, Essack SY, Sartorius B, Patel M, Mlisana KP. Antibiotic resistance trends of ESKAPE pathogens in Kwazulu-Natal, South Africa: A five-year retrospective analysis. Afr J Lab Med. 2018;7:887.

37. Nwadike VU, Ojide CK, Kalu El. Multidrug Resistant Acinetobacter Infection and Their Antimicrobial Suceptibility Pattern in a Nigerian Tertiary Hospital ICU. Afr J Infect Dis. 2014;8:14-8.

38. Čivljak R, Giannella M, Di Bella $S$, Petrosillo N. Could chloramphenicol be used against ESKAPE pathogens? A review of in vitro data in the literature from the $21^{\text {st }}$ century. Expert Rev Anti Infect Ther. 2014;12:249-64.

39. Chika E, Malachy U, Ifeanyichukwu I, Peter E, Thaddeus G, Charles E. Phenotypic detection of metallo-b-lactamase (MBL) enzyme in Enugu, Southeast Nigeria. Am J Biol Chem Pharm Sci. 2014;2:1-6.

40. Cooke F, Wain J. The emergence of antibiotic resistance in typhoid fever. Travel Med Infect Dis. 2004;2:67-74.

41. Kariuki S, Revathi G, Kariuki N, Kiiru J, Mwituria J, Hart CA. Characterisation of community acquired non-typhoidal Salmonella from bacteraemia and diarrhoeal infections in children admitted to hospital in Nairobi, Kenya. BMC Microbiol. 2006;6:101.

42. Berkley JA, Lowe BS, Mwangi I, Williams T, Bauni E, Mwarumba S, Ngetsa C, Slack MP, Njenga S, Hart CA, Maitland K, English M, Marsh K, Scott JA. Bacteremia among children admitted to a rural hospital in Kenya. N Engl J Med. 2005;352:39-47.

43. Eibach D, Belmar Campos C, Krumkamp R, Al-Emran HM, Dekker D, Boahen KG, Kreuels B, Adu-Sarkodie Y, Aepfelbacher M, Park SE, Panzner U, Marks F, May J. Extended spectrum beta-lactamase producing Enterobacteriaceae causing bloodstream infections in rural Ghana, 2007-2012. Int J Med Microbiol. 2016;306:249-54.

44. Maltha J, Guiraud I, Kabore B, Lompo P, Ley B, Bottieau E, Geet C, Tinto $\mathrm{H}$, Jacobs J. Frequency of Severe Malaria and Invasive Bacterial Infections among Children Admitted to a Rural Hospital in Burkina Faso. PLoS One. 2014;9:e89103.

45. Phoba MF, Barbé B, Lunguya 0 , Masendu L, Lulengwa D, Dougan G, Wong VK, Bertrand S, Ceyssens PJ, Jacobs J, Van Puyvelde S, Deborggraeve S. Salmonella enterica serovar Typhi Producing CTX-M-15 Extended Spectrum $\beta$-Lactamase in the Democratic Republic of the Congo. Clin Infect Dis. 2017;65:1229-31.

46. Dagnra AY, Akolly K, Gbadoe A, Aho K, David M. Emergence of multidrug resistant Salmonella strains in Lome (Togo). Med Mal Infect. 2007;37:266-9.

47. Nielsen MV, Sarpong N, Krumkamp R, Dekker D, Loag W, Amemasor S, Agyekum A, Marks F, Huenger F, Krefis AC, Hagen RM, Adu-Sarkodie Y, May J, Schwarz NG. Incidence and characteristics of bacteremia among children in Rural Ghana. PLoS One. 2012;7e44063.

48. Akinyemi KO, Bamiro BS, Coker AO. Salmonellosis in Lagos, Nigeria: incidence of Plasmodium falciparum-associated co-infection, patterns of antimicrobial resistance, and emergence of reduced susceptibility to fluoroquinolones. J Health Popul Nutr. 2007;25:351-8.

49. Kariuki S, Revathi G, Kiiru J, Mengo DM, Mwituria J, Muyodi J, Munyalo A, Teo YY, Holt KE, Kingsley RA, Dougan G. Typhoid in Kenya is associated with a dominant multidrug-resistant Salmonella enterica serovar Typhi haplotype that is also widespread in Southeast Asia. J Clin Microbiol. 2010;48:2171-6.

50. Breiman RF, Cosmas L, Njuguna $H$, Audi A, Olack B, Ochieng JB, Wamola $\mathrm{N}$, Bigogo GM, Awiti G, Tabu CW, Burke H, Williamson J, Oundo JO, Mintz 
ED, Feikin DR. Population-based incidence of typhoid fever in an urban informal settlement and a rural area in Kenya: implications for typhoid vaccine use in Africa. PLoS One. 2012;7:e29119.

51. Phoba MF, Lunguya O, Mayimon DV, Lewo di Mputu P, Bertrand S, Vanhoof R, Verhaegen J, Van Geet C, Muyembe JJ, Jacobs J. Multidrug-resistant Salmonella enterica, Democratic Republic of the Congo. Emerg Infect Dis. 2012;18:1692-4.

52. Kariuki S, Gilks C, Revathi G, Hart CA. Genotypic analysis of multidrugresistant Salmonella enterica serovar Typhi, Kenya. Emerg Infect Dis. 2000;6:649-51.

53. Smith AM, Govender N, Keddy KH; Group for Enteric, Respiratory and Meningeal Disease Surveillance in South Africa (GERMS-SA). Quinoloneresistant Salmonella Typhi in South Africa, 2003-2007. Epidemiol Infect. 2010;138:86-90.

54. Srikantiah P, Girgis FY, Luby SP, Jennings G, Wasfy MO, Crump JA, Hoekstra RM, Anwer M, Mahoney FJ. Population-based surveillance of typhoid fever in Egypt. Am J Trop Med Hyg. 2006;74:114-9.

55. Kiiru J, Kariuki S, Goddeeris B, Butaye P. Analysis of $\beta$-lactamase phenotypes and carriage of selected $\beta$-lactamase genes among Escherichia coli strains obtained from Kenyan patients during an 18-year period. BMC Microbiol. 2012;12:155.

56. Kariuki S, Dougan G. Antibacterial resistance in sub-Saharan Africa: an underestimated emergency. Ann N Y Acad Sci. 2014;1323:43-55.

57. Seni J, Najjuka C, Kateete D, Makobore P, Jolobo M, Kajumbula H, Kapesa A, Bwanga F. Antibacterial resistance in hospitalized surgical patients: a silently emerging public health concern in Uganda. BMC Res Notes. 2013;6:298

58. Vila J, Vargas M, Casals C, Urassa $H$, Mshinda $H$, Schellemberg D, Gascon J. Antimicrobial resistance of diarrheagenic Escherichia coli isolated from children under the age of 5 years from Ifakara, Tanzania. Antimicrob Agents Chemother. 1999;43:3022-4.

59. Okeke IN, Lamikanra A, Czeczulin J, Dubovsky F, Kaper JB, Nataro JP. Heterogeneous virulence of enteroaggregative Escherichia coli strains isolated from children in Southwest Nigeria. J Infect Dis. 2000;181:252-60.

60. Presterl E, Zwick RH, Reichmann S, Aichelburg A, Winkler S, Kremsner PG, Graninger W. Frequency and virulence properties of diarrheagenic Escherichia coli in children with diarrhea in Gabon. Am J Trop Med Hyg. 2003;69:406-10.

61. Okeke IN, Nataro JP. Enteroaggregative Escherichia coli. Lancet Infect Dis. 2001;1:304-13.

62. Nys S, Okeke IN, Kariuki S, Dinant GJ, Driessen C, Stobberingh EE. Antibiotic resistance of faecal Escherichia coli from healthy volunteers from eight developing countries. J Antimicrob Chemother. 2004;54:952-5.

63. Kelly AM, Mathema B, Larson EL. Carbapenem-resistant Enterobacteriaceae in the community: a scoping review. Int J Antimicrob Agents. 2017;50:12734.

64. Siegel JD, Rhinehart E, Cic RNMPH, Jackson M, Brennan PJ, Bell M. Management of multidrug-resistant Organisms In Healthcare Settings, 2006. Am J Infect Control. 2007;3:65-193.

65. Goetz AM, Rihs JD, Wagener MM, Muder RR. Infection and colonization with vancomycin-resistant Enterococcus faecium in an acute care Veterans Affairs Medical Center: a 2-year survey. Am J Infect Control. 1998;26:558-62.

66. Dortet L, Poirel L, Nordmann P. Worldwide dissemination of the NDMtype carbapenemases in Gram-negative bacteria. Biomed Res Int. 2014;2014:249856.

67. Tischendorf J, de Avila RA, Safdar N. Risk of infection following colonization with carbapenem-resistant Enterobacteriaceae: a systematic review. Am J Infect Control. 2016;44:539-43.

68. Codjoe FS, Donkor ES. Carbapenem Resistance: A Review. Med Sci (Basel). 2018:6.
69. Kumarasamy KK, Toleman MA, Walsh TR, Bagaria J, Butt F, Balakrishnan R, Chaudhary U, Doumith $M$, Giske CG, Irfan S, Krishnan P, Kumar AV, Maharjan S, Mushtaq S, Noorie T, Paterson DL, Pearson A, Perry C, Pike R, Rao B, Ray U, Sarma JB, Sharma M, Sheridan E, Thirunarayan MA, Turton J, Upadhyay S, Warner M, Welfare W, Livermore DM, Woodford N. Emergence of a new antibiotic resistance mechanism in India, Pakistan, and the UK: a molecular, biological, and epidemiological study. Lancet Infect Dis. 2010;10:597-602.

70. Sekyere JO, Govinden U, Essack S. The Molecular Epidemiology and Genetic Environment. Microb Drug Resist. 2015;22:59-68.

71. Rodriguez-Martinez JM, Nordmann P, Fortineau N, Poirel L. VIM-19, a metallo-b-lactamase with increased carbapenemase activity from Escherichia coli and Klebsiella pneumoniae. Antimicrob Agents Chemother. 2010;54:471-6.

72. Ktari S, Arlet G, Mnif B, Gautier V, Mahjoubi F, Ben Jmeaa M, Bouaziz $\mathrm{M}$, Hammami A. Emergence of multi-drug-resistant Klebsiella pneumoniae isolates producing VIM-4 metallo-beta-lactamase, CTX-M-15 extended spectrum beta-lactamase and CMY-4 AmpC beta-lactamase in a Tunisian University hospital. Antimicrob Agents Chemother. 2006;50:4198-201.

73. Bathoorn E, Friedrich AW, Zhou K, Arends JP, Borst DM, Grundmann H, Rossen. JW. Latent introduction to the Netherlands of multiple antibiotic resistance including NDM-1 after hospitalisation in Egypt, August 2013. Euro Surveill. 2013;18:20610.

74. Perovic 0 , Britz E, Chetty V, Singh-Moodley A. Molecular detection of carbapenemase-producing genes in referral Enterobacteriaceae in South Africa: A short report. S Afr Med J. 2016;106:975-7.

75. Brink A, Coetzee J, Clay C, Corcoran C, van Greune J, Deetlefs JD, Nutt L, Feldman C, Richards G, Nordmann P, Poirel L. The spread of carbapenemresistant Enterobacteriaceae in South Africa: Risk factors for acquisition and prevention. S Afr Med J. 2012;102:599-601.

76. Lowman W, Sriruttan C, Nana T, Bosman N, Duse A, Venturas J, Clay C, Coetzee J. NDM-1 has arrived: first report of a carbapenem resistance mechanism in South Africa. S Afr Med J. 2011;101:873-5.

77. Yusuf I, Yushau M, Sharif AA, Getso MI, Yahaya H, Bala JA, Aliyu IA, Haruna M. Detection of metallo betalactamases among Gram negative bacterial isolates from Murtala Muhammad Specialist Hospital, Kano and Almadina Hospital Kaduna, Nigeria. Bayero J Pure Appl Sci. 2012;5:84-8.

78. Codjoe FS. Detection and Characterisation of Carbapenem-Resistant GramNegative Bacilli Infections in Ghana (thesis). Sheffield, Sheffield Hallam University, UK. 2016.

79. Ogbolu DO, Webber MA. High-level and novel mechanisms of carbapenem resistance in Gram-negative bacteria from tertiary hospitals in Nigeria. Int J Antimicrob Agents. 2014;43:412-7.

80. Okoche D, Asiimwe BB, Katabazi FA, Kato L, Najjuka CF. Prevalence and Characterization of Carbapenem-Resistant Enterobacteriaceae Isolated from Mulago National Referral Hospital, Uganda. PLoS One. 2015;10:e0135745.

81. Poirel L, Revathi G, Bernabeu S, Nordmann P. Detection of NDM-1producing Klebsiella pneumoniae in Kenya. Antimicrob Agents Chemother. 2011;55:934-6.

82. Mushi MF, Mshana SE, Imirzalioglu C, Bwanga F. Carbapenemase genes among multidrug resistant Gram negative clinical isolates from a tertiary hospital in Mwanza, Tanzania. Biomed Res Int. 2014;2014:303104.

83. Robin F, Aggoune-Khinache N, Delmas J, Naim M, Bonnet R. Novel VIM metallo-betalactamase variant from clinical isolates of Enterobacteriaceae from Algeria. Antimicrob Agents Chemother. 2010;54:466-70.

84. Kieffer N, Nordmann P, Aires-de-Sousa M, Poirel L. High prevalence of carbapenemase-producing Enterobacteriaceae among hospitalized children in Luanda, Angola. Antimicrob Agents Chemother. 2016;60:6189-92. 
85. Moussounda M, Diene SM, Dos Santos $S$, Goudeau A, Francois $P$, van der Mee-MarquetN. Emergence of bla NDM-7 producing Enterobacteriaceae in Gabon, 2016. Emerg Infect Dis. 2017;23:356-8.

86. Mitgang EA, Hartley DM, Malchione MD, Koch M, Goodman JL. Review and Mapping of Carbapenem-resistant Enterobacteriaceae in Africa: Using Diverse Data to Inform Surveillance Gaps. Int J Antimicrob Agents. 2018;52:372-84.

87. Sangare $S A$, Rondinaud E, Maataoui N, Maiga Al, Guindo I, Maiga A, Camara N, Dicko OA, Dao S, Diallo S, Bougoudogo F, Andremont A, Maiga II, ArmandLefevre L. Very high prevalence of extended-spectrum beta-lactamaseproducing Enterobacteriaceae in bacteriemic patients hospitalized in teaching hospitals in Bamako, Mali. PloS One. 2017;12:e0172652.

88. Ndihokubwayo JB, Yahaya AA, Desta AT, Ki-zerbo G. Antimicrobialresistance in the African Region: Issues, challenges and actions proposed, African Health Monitor. 2013;16:27-30.

89. Jiang $X$, Zhang Z, Li M, Zhou D, Ruan F, Lu Y. Detection of extendedspectrum beta-lactamases in clinical isolates of Pseudomonas aeruginosa. Antimicrob Agents Chemother. 2006;50:2990-5.

90. Lee K, Lim YS, Yong D, Yum JH, Chong Y. Evaluation of the Hodge test and the imipenem-EDTA double-disk synergy test for differentiating metallobeta-lactamase-producing isolates of Pseudomonas spp. and Acinetobacter spp. J Clin Microbiol. 2003;41:4623-9.

91. Pournaras S, Poulou A, Tsakris A. Inhibitor-based methods for the detection of KPC carbapenemase-producing Enterobacteriaceae in clinical practice by using boronic acid compounds. J Antimicrob Chemother. 2010;65:131921.

92. Tsakris A, Kristo I, Poulou A, Themeli-Digalaki K, Ikonomidis A, Petropoulou $D$, Pournaras S, Sofianou D. Evaluation of boronic acid disc tests for differentiating KPC-possessing Klebsiella pneumoniae isolates in the clinical laboratory. J Clin Microbiol. 2009;47:362-7.
93. Pasteran F, Veliz O, Rapoport M, Guerriero L, Corso A. Sensitive and specific modified Hodge test for KPC and metallo-beta-lactamase detection in Pseudomonas aeruginosa by use of a novel indicator strain, Klebsiella pneumoniae ATCC 700603. J Clin Microbiol. 2011;49:4301-3.

94. Dunne WM Jr, Hardin DJ. Use of several inducer and substrate antibiotic combinations in a disk approximation assay format to screen for AmpC induction in patient isolates of Pseudomonas aeruginosa, Enterobacter spp., Citrobacter spp., and Serratia spp. J Clin Microbiol. 2005;43:5945-9.

95. Pournaras S, Maniati M, Spanakis N, Ikonomidis A, Tassios PT, Tsakris A Legakis NJ, Maniatis AN. Spread of efflux pump-overexpressing, nonmetallo-beta-lactamase-producing, meropenem-resistant but ceftazidimesusceptible Pseudomonas aeruginosa in a region with blaVIM endemicity. J Antimicrob Chemother. 2005;56:761-4.

96. Anjum MF, Zankari E, Hasman H. Molecular Methods for Detection of Antimicrobial Resistance. Microbiol Spectr. 2017:5.

97. March-Rosselló GA. Rapid methods for detection of bacterial resistance to antibiotics. Enferm Infecc Microbiol Clin. 2017;35:182-8.

98. Snitkin ES, Zelazny AM, Thomas PJ, Stock F; NISC Comparative Sequencing Program Group; Henderson DK, Palmore TN, Segre JA. Tracking a hospital outbreak of carbapenem-resistant Klebsiella pneumoniae with wholegenome sequencing. Sci Transl Med. 2012;4:148ra16.

99. Hrabak J, Chudackova E, Papagiannitsis CC. Detection of carbapenemases in Enterobacteriaceae: a challenge for diagnostic microbiological laboratories. Clin Microbiol Infect. 2014;20:839-53.

100. Ampaire L, Muhindo A, Orikiriza P, Mwanga-Amumpaire J, Bebell L, Boum Y. A review of antimicrobial resistance in East Africa. Afr J Lab Med. 2016;5:432. 